\title{
Survey of Banana Fusarium Fruit Rot under South Gujarat Condition
}

\author{
T. T. Baria*, K. B. Rakholiya and A. K. Chaudhari \\ Department of Plant Pathology, N.M. College of Agriculture, Navsari Agricultural University, \\ NAVSARI, GUJARAT, 396 450, India \\ *Corresponding author
}

\begin{tabular}{|c|c|}
\hline & A B S T R A C T \\
\hline $\begin{array}{l}\text { Ke y w o r d s } \\
\text { Banana, Fusarium } \\
\text { fruit rot, Fusarium } \\
\text { musae, Market } \\
\text { survey, } \\
\text { Post harvest }\end{array}$ & \multirow{3}{*}{$\begin{array}{l}\text { This survey was carried out to identify the Fusarium musae for postharvest } \\
\text { deterioration of banana fruits. The weekly survey carried out from the first } \\
\text { week of June to fourth week of December, } 2017 \text { and } 2018 \text { revealed the } \\
\text { presence of fusarium fruit rot at two locations of Navsari and Surat market } \\
\text { for assessing the disease incidence. The highest incidence of banana } \\
\text { fusarium fruit rot } 10.80 \% \text { and } 11.00 \% \text { were recorded in } 3^{\text {rd }} \text { week of } \\
\text { September and } 2^{\text {nd }} \text { week of September in Navsari market during } 2017 \text { and } \\
2018 \text {, respectively. Whereas, in Surat market, highest incidence of banana } \\
\text { fusarium fruit rot } 12.60 \% \text { and } 11.60 \% \text { were recorded in } 2^{\text {nd }} \text { week of } \\
\text { September during } 2017 \text { and } 2018 \text {, respectively. }\end{array}$} \\
\hline Article Info & \\
\hline $\begin{array}{l}\text { Accepted: } \\
\text { 20 February } 2020 \\
\text { Available Online: } \\
10 \text { March } 2020\end{array}$ & \\
\hline
\end{tabular}

\section{Introduction}

Banana (Musa paradisiaca L.) is one of the most important commercial fruit crop grown all over the world in the tropical and subtropical areas. It is the second largest fruit crop, belongs to family Musaceae in order Zingiberales. It is the most important fruit crop of south Gujarat region. The farmers prefer it because of its high demand as a fresh fruit in the market. Cultivated banana is susceptible to many diseases, mostly fungal pathogen which attacks various part of the plant from root to fruit. Bananas are highly perishable commodities with post-harvest losses estimated up to 25-30 per cent (Kachwaha et al., 1991). Banana fruit suffers from many serious diseases such ascrown-rot, anthracnose, pitting disease, squirter disease, fruit rot, finger-stalk rot, brown specks on fruit, cigar-end rot of fruit and brown spot disease are reported from different parts of the world. The current postharvest problems for bananas are mainly concerned with storage and marketing. The banana fruit infecting fungus Fusarium musae Van Hove was originally known as a distinct population within Fusarium verticillioides. An alternative hypothesis is that Fusarium musae is not only present on banana fruits, but also on other plant hosts or environmental sources (Triesta et al., 2016). Post harvest diseases caused by various microbes had considerable influence nutritive value, harvesting, 
transhipment and storage of fruits. However, much attention need to be paid to the studies on the economic aspect of fungal disease encountered during storage condition and it is necessary to stress upon finding the ways and means of saving the fruits from infection by various pathogenic microorganisms. In this connection, present investigation was undertaken to study the disease prevalence in Navsari and Surat markets.

\section{Materials and Methods}

Survey of fusarium fruit rot of banana was carried out at weekly intervals at Navsari market, Surat market and Horticulture and Organic Farm Navsari, for starting from 2017-18 to 2018-19. Five samples were selected randomly from retailers each containing 100 fruits from both the locations of market and was examined for the per cent disease incidence at each visit was calculate. Infected fruits representing different symptoms were collect at each visit and brought to the laboratory for isolation and symptomatological studies. The per cent fusarium fruit rot incidence was calculated by following standard formula given by Panse and Sukhatme (1985).

Per cent incidence $=$

Number of infected fruits

Total number of fruits X 100

\section{Results and Discussion}

The weekly survey carried out from the first week of June to fourth week of December during 2017 and 2018 revealed the presence of fusarium fruit rot at Navsari and Surat market for assessing the disease incidence of banana. The results of the survey are presented in table 1 and 2 . The results indicated that the average of per cent disease incidence ranged from 6.47 to 6.67 per cent during 2017 and 7.67 to 7.45 per cent during 2018 at Navsari market and Surat market, respectively.

\section{Disease incidence of fusarium fruit rot of banana during 2017 in Navsari market}

The data presented in tablelindicated that at Navsari market. The highest incidence of banana fusarium fruit rot $(10.80 \%)$ was recorded in $3^{\text {rd }}$ week of September followed by $2^{\text {nd }}$ week of September $(10.00 \%)$. Whereas, lowest per cent disease incidence was recorded in $1^{\text {st }}$ week of June i.e., $0.60 \%$ during 2017.

\section{Disease incidence of fusarium fruit rot of banana during 2018 in Navsari market}

The data presented in table lindicated that at Navsari market. The highest incidence of banana fusarium fruit rot $(11.00 \%)$ was recorded in $2^{\text {nd }}$ week of September followed by $3^{\text {rd }}$ week of September $(10.40 \%)$. Whereas, lowest per cent disease incidence was recorded in $1^{\text {st }}$ week of June i.e., $1.40 \%$ during 2018.

\section{Disease incidence of fusarium fruit rot of banana during 2017in Surat market}

The data presented in table 2 indicated that at Surat market. The highest incidence of banana fusarium fruit rot $(12.60 \%)$ was recorded in $2^{\text {nd }}$ week of September followed by $3^{\text {rd }}$ week of September(11.80\%). Whereas, lowest per cent disease incidence was recorded in $2^{\text {nd }}$ week of June i.e., 2.20\% during 2017.

\section{Disease incidence of fusarium fruit rot of banana during 2018in Surat market}

The data presented in table 2indicated that at Surat market. The highest incidence of banana fusarium fruit rot $(11.60 \%)$ was recorded in $2^{\text {nd }}$ week of September followed by $1^{\text {st }}$ week of September $(10.00 \%)$. Whereas, lowest per cent disease incidence was recorded in $3^{\text {rd }}$ week of June i.e., 2.00\% during 2018. 
The result was support with different scientist. Desai (1973) carried out survey at Navsari, Surat, Gandevi and Bardoli under south Gujarat condition and indicated that eight fungal and bacterial diseases associated with banana viz., Fusarium fruit rot, deightoniella fruit spot, tip end rot, cigar end rot, black tip disease, dothiorella fruit spot, immature fruit rot and heart streaking splitting disease. Joshi (1985) surveyed of field and market of south Gujarat and reported various pre and post- harvest diseases of banana viz., main stalk rot, crown rot, neak rot, watery fruit rot, cigar end rot, black spot, spitting peel, anthracnose, squirter disease, tip rot and premature ripening. Aoudou and Phalon (2017) surveyed markets located at Western Region, of Cameroon and recorded Aspergillus, Colletotrichum, Fasarium and Veticillium were the most common genera that colonized banana, mango and safou fruits with different incidences.

Table.1 Incidence of banana fusarium fruit rot at Navsari market during 2017 and 2018

\begin{tabular}{|c|c|c|c|c|}
\hline \multirow{2}{*}{ Sr. No. } & \multirow[t]{2}{*}{ Month } & \multirow[t]{2}{*}{ Week } & \multicolumn{2}{|c|}{ Per cent disease incidence } \\
\hline & & & 2017 & 2018 \\
\hline 1 & \multirow[t]{4}{*}{ June } & I & 0.60 & 1.40 \\
\hline 2 & & II & 1.60 & 1.80 \\
\hline 3 & & III & 3.40 & 3.80 \\
\hline 4 & & IV & 3.80 & 4.00 \\
\hline 5 & \multirow[t]{4}{*}{ July } & I & 4.00 & 5.40 \\
\hline 6 & & II & 4.80 & 4.60 \\
\hline 7 & & III & 5.60 & 5.60 \\
\hline 8 & & IV & 7.00 & 6.60 \\
\hline 9 & \multirow[t]{4}{*}{ August } & I & 7.80 & 8.00 \\
\hline 10 & & II & 8.60 & 8.80 \\
\hline 11 & & III & 7.80 & 9.00 \\
\hline 12 & & IV & 8.00 & 7.60 \\
\hline 13 & \multirow[t]{4}{*}{ September } & I & 7.00 & 8.00 \\
\hline 14 & & II & 10.00 & 11.00 \\
\hline 15 & & III & 10.80 & 10.40 \\
\hline 16 & & IV & 7.80 & 8.00 \\
\hline 17 & \multirow[t]{4}{*}{ October } & I & 8.00 & 8.00 \\
\hline 18 & & II & 8.40 & 8.20 \\
\hline 19 & & III & 6.60 & 7.00 \\
\hline 20 & & IV & 7.60 & 8.20 \\
\hline 21 & \multirow[t]{4}{*}{ November } & I & 6.60 & 6.40 \\
\hline 22 & & II & 7.40 & 7.40 \\
\hline 23 & & III & 7.80 & 8.20 \\
\hline 24 & & IV & 7.00 & 6.60 \\
\hline 25 & \multirow[t]{4}{*}{ December } & I & 6.60 & 5.80 \\
\hline 26 & & II & 5.60 & 5.40 \\
\hline 27 & & III & 5.80 & 5.60 \\
\hline 28 & & IV & 5.20 & 6.00 \\
\hline \multicolumn{3}{|c|}{ Mean } & 6.47 & 6.67 \\
\hline
\end{tabular}


Table.2 Incidence of banana fusarium fruit rot at Surat market during 2017 and 2018

\begin{tabular}{|c|c|c|c|c|}
\hline \multirow[t]{2}{*}{ Sr. No. } & \multirow[t]{2}{*}{ Month } & \multirow[t]{2}{*}{ Week } & \multicolumn{2}{|c|}{ Per cent disease incidence } \\
\hline & & & 2017 & 2018 \\
\hline 1 & \multirow[t]{4}{*}{ June } & I & 2.40 & 3.40 \\
\hline 2 & & II & 2.20 & 3.80 \\
\hline 3 & & III & 3.80 & 2.00 \\
\hline 4 & & IV & 3.60 & 2.20 \\
\hline 5 & \multirow[t]{4}{*}{ July } & I & 5.40 & 6.20 \\
\hline 6 & & II & 6.20 & 5.40 \\
\hline 7 & & III & 6.80 & 6.40 \\
\hline 8 & & IV & 7.60 & 7.40 \\
\hline 9 & \multirow[t]{4}{*}{ August } & $\mathrm{I}$ & 9.60 & 9.00 \\
\hline 10 & & II & 10.20 & 9.20 \\
\hline 11 & & III & 9.40 & 9.60 \\
\hline 12 & & IV & 9.80 & 8.80 \\
\hline 13 & \multirow[t]{4}{*}{ September } & I & 9.00 & 10.00 \\
\hline 14 & & II & 12.60 & 11.60 \\
\hline 15 & & III & 11.80 & 9.60 \\
\hline 16 & & IV & 9.60 & 9.00 \\
\hline 17 & \multirow[t]{4}{*}{ October } & I & 8.80 & 9.60 \\
\hline 18 & & II & 9.40 & 8.60 \\
\hline 19 & & III & 7.60 & 7.60 \\
\hline 20 & & IV & 8.20 & 9.00 \\
\hline 21 & \multirow[t]{4}{*}{ November } & I & 7.40 & 7.00 \\
\hline 22 & & II & 8.40 & 8.00 \\
\hline 23 & & III & 9.00 & 9.00 \\
\hline 24 & & IV & 8.40 & 8.00 \\
\hline 25 & \multirow[t]{4}{*}{ December } & I & 7.40 & 6.60 \\
\hline 26 & & II & 6.40 & 6.00 \\
\hline 27 & & III & 7.20 & 7.60 \\
\hline 28 & & IV & 6.60 & 8.00 \\
\hline \multicolumn{3}{|c|}{ Mean } & 7.67 & 7.45 \\
\hline
\end{tabular}

\section{References}

Aoudou, Y. and Phalon, M. E. G. (2017). Isolation and pathogenicity evaluation of post harvest fungal of some fruits in Cameroon. International Journal of Environment, Agriculture and Biotechnology, 2(1): 56-60. art/BQ/7-3-376-434.pdf Desai, M. B. (1973). Studies regarding some of the fruit diseases banana occurring in south Gujarat area. M.Sc.(Agri.) thesis submitted to GAU, S. K. nagar.

Joshi, K. R. (1985). Invastigation upon pre and post harvest fruit diseases of banana prevalent under south Gujarat area. Ph.D.(Agri.) thesis submitted to GAU, S. K. nagar.

Kachwaha, M., Chile, A. K., Mehta, A and Mehta, P. (1991). A new fruit rot 
disease of banana. Indian Phytopathology, 43: 211-215

Panse, V. G. and Sukhatme P. V. (1985). Statistical Methods for Agricultural Workers. New Delhi, ICAR, 145-8. http://www.chemijournal.com/archives/ 2019/vol7issues3/P

Triesta, D., Pierard, D., Cremerc, K. D. and
Hendrick, M. (2016). Fusarium musae infected banana fruits as potential source of human fusariosis: May occur more frequently than we might think and hypotheses about infection. Communicative \& Integrative biology, 9(2): e1162934.

\section{How to cite this article:}

Baria, T. T., K. B. Rakholiya and Chaudhari, A. K. 2020. Survey of Banana Fusarium Fruit Rot under South Gujarat Condition. Int.J.Curr.Microbiol.App.Sci. 9(03): 2618-2622.

doi: https://doi.org/10.20546/ijcmas.2020.903.299 